\title{
Differences in the Perception of E-Learning Resources: A Cross-Cultural Analysis of Logistics Students in Austria and the Czech Republic
}

\author{
${ }^{1}$ Martina Gaisch, ${ }^{2}$ Victoria Rammer, ${ }^{3}$ Jan Gregor, ${ }^{4}$ Libuše Turinská \\ ${ }^{1,2}$ University of Applied Sciences Upper Austria, Hagenberg, Austria \\ ${ }^{3,4}$ The Institute of Technology and Business in České Budějovice, Czech Republic
}

\begin{tabular}{|c|c|}
\hline & ABSTRACT \\
\hline 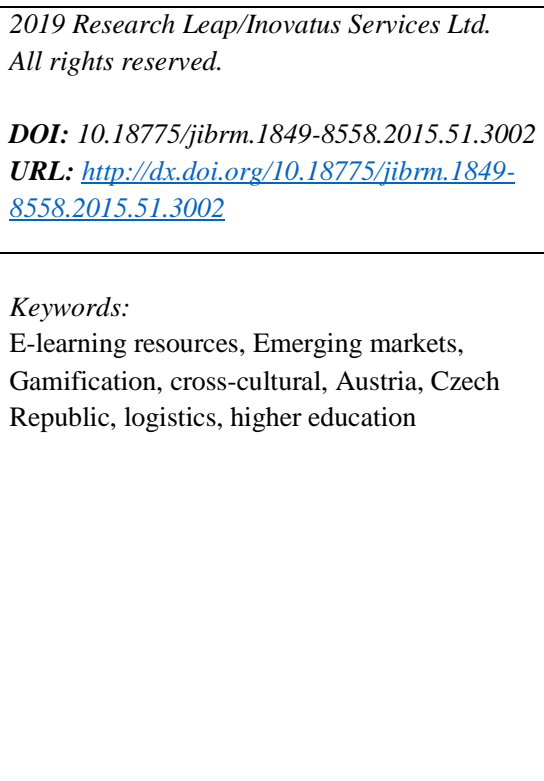 & $\begin{array}{l}\text { The aim of this study is to analyse and compare online learning preferences of higher education } \\
\text { students taking a degree in logistics both in Austria and the Czech Republic. It is sought to grasp } \\
\text { aspects that support the acceptance of online learning material and to identify how learning styles } \\
\text { and societal and disciplinary cultures influence the perception of e-learning resources. In this } \\
\text { context, the acceptance of gamification elements is investigated in more detail to shed light on the } \\
\text { preferences of the respective learning culture. This investigation is embedded in a larger EU project } \\
\text { that seeks to foster cross-border cooperation between two technical oriented higher education } \\
\text { institutions and the local industry. Due to increasing international cooperation and emerging } \\
\text { markets, a profound understanding of multinational aspects as well as the differences in } \\
\text { geographical perspectives have become major drivers for international business. Within this project } \\
\text { it is intended to produce e-learning material for four technical disciplines that can be used by } \\
\text { students and regional employees of these fields. To make most practical use of the provided e- } \\
\text { learning resources, it is critical to know about the contextual differences and the learning preferences } \\
\text { of each disciplinary and societal learning group. The focus of the present investigation is placed on } \\
\text { logistics only. To get deeper insight into the perception of logistics students with regard to e-learning } \\
\text { resources, a questionnaire was set up and distributed among Bachelor students at both sides of the } \\
\text { border. It was found that apart from individual factors such as openness to learning opportunities or } \\
\text { independence of learning, also the respective subject area and the cultural and institutional attitude } \\
\text { towards e-learning have substantial impact on the learning behaviour and the individual perception } \\
\text { of what constitutes a valuable e-learning resource. }\end{array}$ \\
\hline
\end{tabular}

\section{Introduction}

In recent years, internationalization and globalization in both academia and industry have become a major driver for crossborder cooperation. Due to international business activities and the increasingly digitalised world, new skill-sets and learning settings have emerged that should add to the knowledge base of prospective graduates. In addition, a number of research projects are funded between different geographical regions with the aim to encourage the exchange of good practice examples. Learning from each other and also increasing awareness of differences and similarities across the borders are essential ingredients for peaceful relations of neighbouring countries. Further, emerging markets as the one of the Czech Republic generally do not have the level of market efficiency and strict standards in accounting and securities regulation to be on par with advanced economies (Dixit 2015). Here too, it may be a fruitful endeavour to compare differing regulations but also priorities set towards the educational agenda for logistics students. To know their preferred learning styles may be useful to further improve e-learning material and resources and as such educate more efficient and well-versed graduates that can proficiently operate in an international context. This is even more crucial for logistics graduates who need to be able to "integrate, communicate, and analyse from an international perspective, perform financial analysis and maintain good industry and customer relations" (Cmilt 2015, p. 4). Moreover, they need to understand legal requirements and regulations and be capable of contextualising them in a holistic frame.

It is for these reasons that the present contribution seeks to carve out how online learning preferences of logistics students in Austria and the Czech Republic may differ. Given the similarities among the disciplinary groups, cultural differences are foregrounded and analysed in more detail. In the following, the most relevant cultural-specific idiosyncrasies are discussed. 


\section{Theoretical Framework}

\subsection{Cultural Aspects of Austria and the Czech Republic}

Numerous researchers of various scholarly backgrounds and orientations have dealt with the concept of culture and cultural patterns (e.g. Kroeber \& Kluckhohn 1925; Hofstede 1984; Hall 1976: Trompenaars and Hampden-Turner 1997; House et al. 2002; Schroll-Machl \& Nový 2008). Even though culture can be regarded to be an abstract concept that is altered and modified in line with the meaning and the context of the respective subject, the term is generally referred to as a "set of parameters of collectives that differentiate the collectives from each other in meaningful ways" (House et al. 2002, p. 5). Generally understood as a global orientation system, the layered concept of culture predominantly refers to specific values, behaviours and symbols that are typical of certain cultural groups of people. Arguably, within cross-cultural investigations the individual variations are frequently of minor importance and it is often the macro-cultural lens that is adopted to draw on societal patterns. In this context, Hofstede (1984) identified culture as the basis of human thinking, acting and feeling, while others relate to it as a particular system of standards, values, norms and rules that impact the attitudes, behaviours, beliefs and capabilities of people within a specific society (Thomas, Schroll-Machl, Kammhuber \& Kinast 2009). When comparing the differences and similarities of societal cultures, key characteristics can be partitioned into specific dimensions. Although cultural groups within a country can exhibit distinct characteristics which makes it impossible to categorize or standardize dimensions regarding a specific country on an overarching basis (Bolten 2003), there are still specific patterns that seem applicable to certain societal clusters. The theoretical foundation of this investigation is focused on the cultural paradigm proposed by Hofstede (1984) and the cultural standards of Fink, Nový and Schroll-Machl (2000).

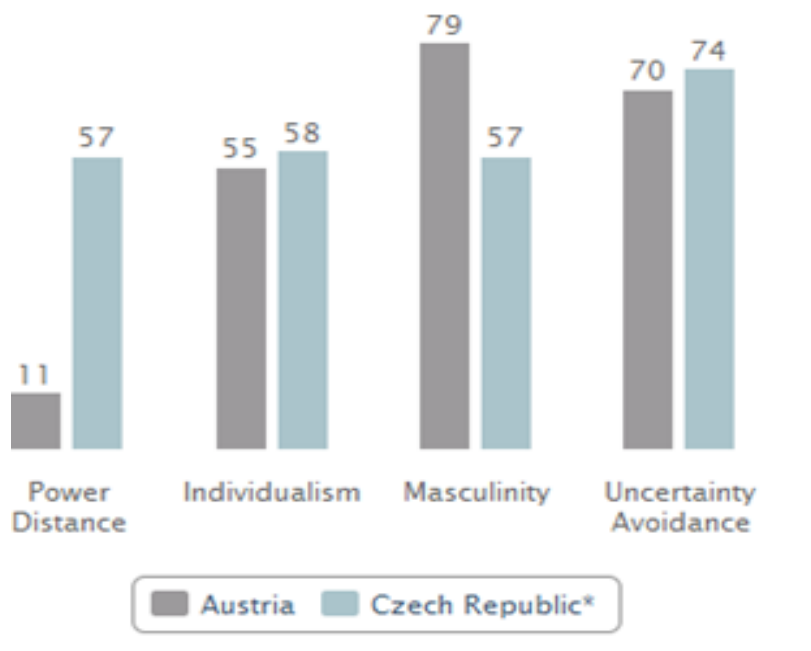

Figure 1: Cultural dimensions of Hofstede (1984)

A When drawing on Hofstede's dimensions (Figure 1) it can be stated that Austria has a substantially lower power distance than the Czech Republic. In this regard, Austria is identified as a country where persons have mostly informal work relations and flat structures and hierarchy is only used for convenience whereas people in the Czech Republic tend to accept hierarchical order and inherent inequalities more easily. Furthermore, both the Czech Republic and Austria are defined as rather individualistic countries with a high scale of uncertainty avoidance. This means that both countries prefer to have loosely-knit social relationships in which individuals predominantly care for themselves and their immediate families. Additionally, as countries with high uncertainty avoidance they tend to have an emotional need for rules and regulations. Another factor where Austria and the Czech Republic seem to differ is the masculinity scale which implies that Austria is more driven by success, achievement and competition than the Czech Republic (Hofstede 1984; Hofstede \& Hofstede 2012, Gaisch et al 2017).

According to Schroll-Machl and Novy (2008) citizens of the Czech Republic tend to be more sceptical of rigid structures and prefer improvisation. They also appreciate it to act more independently and context-sensitively in particular situations. Moreover, it was stated that in contrast to Austria, Czechs show a significantly higher preference towards a diffuse cultural orientation in which the public and the private space tend to be interwoven (Schroll-Machl and Novy 2008). This implies that Czech citizens are more likely to combine business and private life (Trompenaars \& Hampden-Turner 2011) and also have a higher level of involvement in relationship (Trompenaars and Hampden-Turner 1997). In other words, what people from a mainly specific culture may consider of little significance or even as a waste of time may - in a diffuse culture - be regarded as important (Overgaard 2010). As such, personal interests and relationships are seen as more vital than in specific cultures where task-orientation is foregrounded. In this vein, it can be stated that Austrians prefer to work within a rule-based setting where work and private lives are separated. Moreover, Austrians seems to operate less simultaneously than Czechs who seek the opportunity of achieving more than one goal or idea at once (Schroll-Machl and Novy 2008). Interestingly, it was also found that while the German Cluster (House et al. 2002) seems to strictly follow rules, Austria is some kind of exception, as it appears more flexible in this regard and also more willing to bend some regulations under certain circumstances. This would point to a more particularistic behaviour (Trompenaars, 1993) which, in many regards, can also be found in the Czech culture. Such elements are reflected by the unwillingness to follow clearly defined rules.

In addition, it was found that Austrians incline to a stable selfconfidence whereas individuals of the Czech culture commute between humility and hubris, notwithstanding both cultures tend to conflict avoidance in their society (Fink, Nový and Schroll-Machl 2000). 
A recent study (Knap and Nový 2017) on Czech cultural standards as perceived by German managers identified three key features that seem to be typical of Czech citizens, namely propensity for improvisation, avoidance of conflict, and rejection of hierarchical structures. It was also found that $\mathrm{Czech}$ managers showed a tendency to focus on action due to their polychronic perception of time. Direct avoidance of conflict or avoidance through an excuse as well as digression from the topic were also reported to be a typical Czech feature. This may go hand in hand with a higher context in which communication between differing parties is embedded as well as a higher tendency of diffusion, so to say, mix professional and private activities. The findings of this study appear to be in line with those of Nový \& Schroll-Machl, (2015) stating that Czechs tend to be externally oriented and thus more "philosophizing", collectivist, diffuse, and particularistic.

As to the Germanic cultural values, it was found that performance orientation takes the lead, followed by high levels of uncertainty avoidance and assertiveness and low levels of humane orientation (Brodbeck et al. 2002). In this context, it needs to be stated, however, that the defined cultural standards shall only serve as signboards intended to find a quicker path toward mutually successful cooperation and mutual understanding.

\subsection{E-Learning Systems and Gamification}

In view of the complex dynamics of the digitalized era, higher education institutions have started to increasingly implement elearning tools which have become one of the key drivers of current educational systems (Urh, Vokovic, Jereb 2015). In general, e-learning systems support students by improving their skills and gaining new knowledge by using web-based information and communication systems and technologies (Zaric, Scepanović, Vujicic, Ljucovic \& Davcev 2017). In other words, they are cognitive instruments designed to encourage students to learn more independently and actively (Amriani, Aji, Utomo \& Junus 2013). According to Urh et al (2015), higher education institutions seek to "achieve the goals and effects, such as high degree of satisfaction, motivation, effectiveness and efficiency of students" ( $p$ 389) by means of e-learning systems. In addition, e-learning tools aim to support the contact between students and teachers, reciprocity and cooperation between students, communication between all participants as well as the possibility to learn from each other (Shea, Picett \& Pelz 2003).

Within the last decades, a multitude of ways of how to develop, optimize and utilize e-learning systems have emerged. An increasingly popular strategy for implementing online learning environments is to apply gamification elements. Gamification is defined as the use of game design mechanics and elements in non-game contexts (Deterding, Sicart, Nacke, O'Hara \& Dixon 2011). The primary objective when relating gamification with online learning is to enhance the engagement and motivation of learners by using gaming techniques. It is sought to trigger a more engaging and efficient learning behaviour (Muntean 2011) and balance both, e-learning and gamification, to provide the optimal requirement for the so-called state of flow (Urh et al. 2015). The state of flow is characterized by an optimal experience where the learner entirely focuses on the activity at hand. Through the usage of gamification elements such as goals, feedback and rules this flow can be triggered. Consequently, e-learning with an appropriate use of gamification and sufficient consideration of differing learning styles can provide an optimal online learning environment (Urh et.al. 2015; Gaisch \& Jadin 2015; Jadin \& Gaisch 2016).

Learning styles and theories refer to "the preferential way in which the student absorbs processes, comprehends and retains information" (Zaric et al. 2017, p.4). These styles and preferences embrace the psychological and cognitive behaviours of learners. It indicates how students learn and work as well as how they interact with their learning environment (Zaric, et al. 2017). Further, the need for more context-sensitive ways of learning was identified "where fresh and timely approaches for e-learning settings need to be on the daily agenda of an Age of increasingly adaptive expertise" (Gaisch \& Jadin 2015, p. 120).

\section{Research Objectives}

The main objective of this research paper is to identify the contextual differences and online learning preferences of Bachelor students taking a degree in logistics in Austria and the Czech Republic. It is sought to generally detect cross-border differences and by drawing on this cultural knowledge, it is hoped to deliver online material that suits the requirements of the investigated geographical groups. Given that the aim of the Interreg project at hand is to adopt a CLIL (content and language integrated) approach that should positively impact students' foreign language skills and subject learning (DaltonPuffer 2008), it is vital to know how online material should be presented at each side of the border to best reach the intended goals. Further, it is sought to present e-learning resources in such a way that it can also benefit employees of the local industries in Austria and the Czech Republic.

\section{Research Methods}

To identify the preferred online learning preferences and cognitive styles that seem to be best suited for future logistics professionals in Austria and the Czech Republic, a questionnaire was set up. The first block contained questions with regard to cultural values and societal orientations. The second block sought to discover preferred learning styles of logistic students and thus use the generated in-depth knowledge to best compile online course material for the group at hand. The third block zoomed in on issues such as structure, design, usage of visual and/or audio material as well as self-evaluation. In total, the questionnaire consisted of 43 questions. It was distributed among 20 logistics Bachelor students in Austria and 20 logistics Bachelor students in the Czech Republic. Of the 40 
participants with an age range of 18 to 24,21 men and 19 women completed the questionnaire. 10 male and 10 female participants came from Austria and 11 males and 9 females from the Czech Republic. Table 1 gives an overview of the participants. Respondents were asked to rate the questions on a scale of 1 to 5 whereby 1 is total agreement and 5 is total rejection. In doing so, it was sought to explore the extent to which individual factors such as openness to learning opportunities or independence of learning as well as the cultural and institutional attitude towards e-learning impact the learning behaviour. In the following, the results are presented in more detail.

Table 1: Overview of the interview data

\begin{tabular}{lll}
\hline Gender & Male & 21 \\
& Female & 19 \\
\hline Countries & Austria & 20 people \\
& Czech Republic & 20 people \\
\hline Disciplines & Logistic (Bachelor) & 40 people \\
& & \\
\hline Total \\
participants & & 40 participants
\end{tabular}

\section{Findings}

In the following, the main results of the questionnaire are presented and discussed in more detail. For one, it could be demonstrated that the perception of e-learning material as well as the learning preferences with regard to the structure and preparation of content are relatively similar in both countries. Due to this knowledge it is advisable to create coherent elearning content within the framework of this Interreg project. Although the findings indicate several similarities, there are also country-specific differences that need to be taken into account when creating e-learning material.

The results of the research suggest that the Austrian logistics students have a greater tendency towards clear and structured learning objectives than students of the Czech Republic. This may be due to the high levels of assertiveness and task orientation of Austrian learners.

With reference to the question regarding a consistent structure of the learning material to avoid uncertainty, it was found that the Czech respondents had a slightly higher ambiguity tolerance than the ones in Austria. The responses show that a unified form of learning material is perceived as less essential for Czechs. This may be due to their lower uncertainty avoidance and lower power distance in contrast to Austrian respondents (Marcus \& Gould 2000). With reference to Hofstede's findings (1984) the results are not entirely in line with his identified dimensions for Austria and the Czech Republic. While Hofstede (1984) categorizes Austria as a low power culture with less uncertainty avoidance than the Czech Republic, the current study identified the opposite. In this vein, Czech students prefer learning material complied by highly qualified experts which, in turn, seems to also highlight the high power distance within the country. Additionally, Czechs are more likely to be encouraged by learning material that is enriched by multimedia elements. This refers to a high context culture within the Czech Republic (Marcus \& Gould 2000). Furthermore, it can be stated that Austria as a masculine culture with low power distance prefers the usage of multimedia elements only for utilitarian purposes. Interestingly, the findings with regard to the uncertainty avoidance score of Hofstede seem to differ substantially. According to Hofstede (1984), the Czech Republic shows a slightly higher score of this dimension than the Austrian culture, whereas the findings of the research indicate the opposite result. Although the findings outline that students of the Czech Republic are more likely to use multimedia elements, they still tend to have a higher preference towards textually prepared learning material without gamification elements than their Austrian colleagues.

Moreover, it was found that Austrian logistics students have less awareness of gender- sensitive language usage than the Czechs. In this context, literature revealed that countries with a high masculinity scale are more likely to identify themselves through traditional gender roles, family patterns and age distinctions (Marcus \& Gould 2000; Hofstede \& Hofstede 2012). Another finding reveals that students of both countries appreciate the possibility for self- evaluation. Yet, Austrian students show a substantially greater need to assess their own performance than Czech students. Besides, Austrian students are more likely to use evaluation tools for the sake of competition with others. This evident preference for competitive elements is a further indication for a highly masculine culture (Marcus \& Gould 2000; Hofstede \& Hofstede 2012). As to self-evaluation possibilities, the analysis shows no clearly preferred time period as to when the evaluation part should take place. Furthermore, the findings show that learners of the Czech Republic exhibit a greater need for reflective loops. This would be an indication for a reflective learning approach. According to Kolb (1984), reflective learners or assimilators prefer to use and learn theories and define new issues and/or problems. Such learning types prefer reflected observation, theoretical models and abstract conceptualizations (Kolb 1984; Felder \& Silvermann 1988). In contrast to the Czech Republic, Austrian logistics students were identified to be rather active learners who have a preference towards concrete applications and active experimentation (Kolb 1984; Felder \& Soloman 2000). Further, it was found that in Austria practical examples are mainly used to expound details or elaborate on theoretical foundations. This finding may also be ascribed to the fact that the Austrian participants are enrolled at a practice-oriented university of applied sciences, while the Czech participants take their logistics degree at a classical research university. Moreover, Austrian students were found to be more task-oriented than students of the Czech Republic. This also translated in their higher preference for facts, figures and details and their wish to acquire 
some meta-level knowledge. In line with Felder and Soloman (2000), the findings demonstrate that, in contrary to the Czechs, Austrian students are more global learners who tend to be patient with details and put things together in innovative ways once they have captured the big picture. Table 2 represents the main results of this investigation.

Table 2: Main results of the investigation

$1=$ strongly agree, $2=$ agree, $3=$ partly agree, $4=$ disagree, $5=$ strongly disagree

\begin{tabular}{|c|c|c|c|c|c|c|}
\hline & & 1 & 2 & 3 & 4 & 5 \\
\hline \multirow{2}{*}{$\begin{array}{l}\text { Clearly defined learning } \\
\text { objectives are important }\end{array}$} & Austria & 16 & 2 & 2 & 0 & 0 \\
\hline & Czech Republic & 8 & 9 & 3 & 0 & 0 \\
\hline \multirow{2}{*}{$\begin{array}{l}\text { Consistent structure of } \\
\text { learning materials to } \\
\text { avoid ambiguity }\end{array}$} & Austria & 12 & 6 & 1 & 1 & 0 \\
\hline & Czech Republic & 9 & 6 & 4 & 1 & 0 \\
\hline \multirow{2}{*}{$\begin{array}{l}\text { Creation of learning } \\
\text { materials by qualified } \\
\text { experts }\end{array}$} & Austria & 5 & 6 & 8 & 1 & 0 \\
\hline & Czech Republic & 5 & $\begin{array}{l}1 \\
4\end{array}$ & 1 & 0 & 0 \\
\hline \multirow{2}{*}{$\begin{array}{l}\text { Gender-sensitive } \\
\text { language and gender } \\
\text { equality within learning } \\
\text { materials }\end{array}$} & Austria & 2 & 1 & 7 & 4 & 6 \\
\hline & Czech Republic & 4 & 5 & $\begin{array}{l}1 \\
1\end{array}$ & 0 & 0 \\
\hline \multirow{2}{*}{$\begin{array}{ll}\text { Use of } & \text { different } \\
\text { multimedia } & \text { elements } \\
\text { within the learning } \\
\text { materials }\end{array}$} & Austria & 2 & 8 & 9 & 1 & 0 \\
\hline & Czech Republic & 7 & $\begin{array}{l}1 \\
0\end{array}$ & 2 & 1 & 0 \\
\hline \multirow{2}{*}{$\begin{array}{l}\text { Tools for self-evaluation } \\
\text { (quiz, text) to measure } \\
\text { progress }\end{array}$} & Austria & 9 & 9 & 2 & 0 & 0 \\
\hline & Czech Republic & 5 & 5 & 7 & 3 & 0 \\
\hline \multirow{2}{*}{$\begin{array}{lr}\text { Textual } & \text { preparation of } \\
\text { learning } & \text { materials } \\
\text { without } & \text { gamification } \\
\text { elements } & \end{array}$} & Austria & 4 & 0 & 3 & 8 & 5 \\
\hline & Czech Republic & 2 & 5 & 7 & 2 & 4 \\
\hline \multirow{2}{*}{$\begin{array}{l}\text { Understanding of } \\
\text { learning materials } \\
\text { through active working } \\
\text { with the content }\end{array}$} & Austria & 11 & 7 & 2 & 0 & 0 \\
\hline & Czech Republic & 7 & 7 & 4 & 1 & 1 \\
\hline \multirow{2}{*}{$\begin{array}{l}\text { Understanding } \begin{array}{r}\text { of } \\
\text { learning } \\
\text { through } \\
\text { content }\end{array} \\
\end{array}$} & Austria & 3 & 8 & 6 & 3 & 0 \\
\hline & Czech Republic & 9 & 6 & 5 & 0 & 0 \\
\hline \multirow{2}{*}{$\begin{array}{l}\text { Preference of practical } \\
\text { examples }\end{array}$} & Austria & 16 & 3 & 0 & 1 & 0 \\
\hline & Czech Republic & 8 & 7 & 4 & 0 & 1 \\
\hline \multirow{2}{*}{$\begin{array}{l}\text { Preference of facts and } \\
\text { details }\end{array}$} & Austria & 4 & $\begin{array}{l}1 \\
2\end{array}$ & 4 & 0 & 0 \\
\hline & Czech Republic & 3 & 8 & 6 & 3 & 0 \\
\hline \multirow{2}{*}{$\begin{array}{l}\text { Possibilities for } \\
\text { competition }\end{array}$} & Austria & 4 & 3 & 9 & 3 & 1 \\
\hline & Czech Republic & 3 & 5 & 4 & 4 & 4 \\
\hline \multirow{2}{*}{$\begin{array}{l}\text { Getting an overview of } \\
\text { learning content before } \\
\text { learning lessons }\end{array}$} & Austria & 7 & 9 & 4 & 0 & 0 \\
\hline & Czech Republic & 3 & 7 & 4 & 3 & 3 \\
\hline \multirow{2}{*}{$\begin{array}{l}\text { Possibilities for self- } \\
\text { evaluation are } \\
\text { appreciated }\end{array}$} & Austria & 4 & 8 & 8 & 0 & 0 \\
\hline & Czech Republic & 2 & 8 & 7 & 3 & 0 \\
\hline
\end{tabular}

When looking at the third block which deals with the preparation of e-learning material, especially with issues such as structure, design, usage of visual and/or audio material as well as self-evaluation, all participants agree on the importance of logical structure. Nevertheless, it came to the fore that Austrian students have more need for logical cohesion than students of the Czech Republic. This may be due to the low context communication culture of Austria (Marcus \& Gould 2000; Hall, 1967) and also shows that Austrian student have a higher tendency towards a sensing learning style (Felder \& Soloman 2000). Similarly, the majority of students in both countries voice the necessity for a unified structure and form.

Further statements related to the importance of gamification and other elements of e-learning material. It results from the analysis that 13 out of 20 Austrian students prefer the usage of visualisations and tables while in the Czech Republic only 7 participants point out that graphs, figures and charts are helpful. With regard to the usage of mind maps, respondents of both the Czech Republic and Austria indicated that they consider these graphical representations as a useful instrument to gain a more holistic overview of the content.

Moreover, as depicted in Table 3, the use of audio sequences on e-learning slides is more preferred by Czechs. Besides, Austrians and Czechs are marginally different in their approach towards the application of gamification elements. In contrast to Austria, Czech students are more reluctant toward gamification elements while Austrians tend to be more inclined to draw on such elements, also because of their competitive nature. Considering this result, the masculine culture of Austria may be a decisive ingredient for this preference (Marcus \& Gould 2000).

Furthermore, it can be stated that Austrian students are more likely to prefer straight- forward and explicit information to avoid ambiguity. Interestingly, this result is not in line with Hofstede (1984) whose findings point to a higher uncertainty avoidance score within the Czech culture than in Austria. The statements regarding the possibility of self-evaluation at the end of each lesson brought rather different answers. It may be concluded that the students would prefer to have a possibility of a self-evaluation test at the end of each lesson, but do not see it as an inseparable part of the e-learning material. Table 3 provides a summary of the results of the third group of questions. 
Table 3: Block 3 - Layout, visualization and structure of elearning material

$1=$ strongly agree, $2=$ agree, $3=$ partly agree, $4=$ disagree, $5=$ strongly disagree

\begin{tabular}{|c|c|c|c|c|c|c|}
\hline & & 1 & 2 & 3 & 4 & 5 \\
\hline \multirow{2}{*}{$\begin{array}{l}\text { Clearly defined learning } \\
\text { objectives are important }\end{array}$} & Austria & 16 & 2 & 2 & 0 & 0 \\
\hline & Czech Republic & 8 & 9 & 3 & 0 & 0 \\
\hline \multirow{2}{*}{$\begin{array}{l}\text { Consistent structure of } \\
\text { learning materials to } \\
\text { avoid ambiguity }\end{array}$} & Austria & 12 & 6 & 1 & 1 & 0 \\
\hline & Czech Republic & 9 & 6 & 4 & 1 & 0 \\
\hline \multirow{2}{*}{$\begin{array}{l}\text { Creation of learning } \\
\text { materials by qualified } \\
\text { experts }\end{array}$} & Austria & 5 & 6 & 8 & 1 & 0 \\
\hline & Czech Republic & 5 & $\begin{array}{l}1 \\
4\end{array}$ & 1 & 0 & 0 \\
\hline \multirow{2}{*}{$\begin{array}{l}\text { Gender-sensitive } \\
\text { language and gender } \\
\text { equality within learning } \\
\text { materials }\end{array}$} & Austria & 2 & 1 & 7 & 4 & 6 \\
\hline & Czech Republic & 4 & 5 & $\begin{array}{l}1 \\
1\end{array}$ & 0 & 0 \\
\hline \multirow{2}{*}{$\begin{array}{ll}\text { Use of } & \text { different } \\
\text { multimedia } & \text { elements } \\
\text { within the learning } \\
\text { materials }\end{array}$} & Austria & 2 & 8 & 9 & 1 & 0 \\
\hline & Czech Republic & 7 & $\begin{array}{l}1 \\
0 \\
\end{array}$ & 2 & 1 & 0 \\
\hline \multirow{2}{*}{$\begin{array}{l}\text { Tools for self-evaluation } \\
\text { (quiz, text) to measure } \\
\text { progress }\end{array}$} & Austria & 9 & 9 & 2 & 0 & 0 \\
\hline & Czech Republic & 5 & 5 & 7 & 3 & 0 \\
\hline \multirow{2}{*}{$\begin{array}{l}\text { Textual preparation of } \\
\text { learning materials without } \\
\text { gamification elements }\end{array}$} & Austria & 4 & 0 & 3 & 8 & 5 \\
\hline & Czech Republic & 2 & 5 & 7 & 2 & 4 \\
\hline \multirow{2}{*}{$\begin{array}{l}\text { Understanding of learning } \\
\text { materials through active } \\
\text { working with the content }\end{array}$} & Austria & 11 & 7 & 2 & 0 & 0 \\
\hline & Czech Republic & 7 & 7 & 4 & 1 & 1 \\
\hline \multirow{2}{*}{$\begin{array}{l}\text { Understanding of learning } \\
\text { materials through } \\
\text { reflecting the content }\end{array}$} & Austria & 3 & 8 & 6 & 3 & 0 \\
\hline & Czech Republic & 9 & 6 & 5 & 0 & 0 \\
\hline \multirow{2}{*}{$\begin{array}{l}\text { Preference of practical } \\
\text { examples }\end{array}$} & Austria & 16 & 3 & 0 & 1 & 0 \\
\hline & Czech Republic & 8 & 7 & 4 & 0 & 1 \\
\hline \multirow{2}{*}{$\begin{array}{l}\text { Preference of facts and } \\
\text { details }\end{array}$} & Austria & 4 & $\begin{array}{l}1 \\
2\end{array}$ & 4 & 0 & 0 \\
\hline & Czech Republic & 3 & 8 & 6 & 3 & 0 \\
\hline \multirow{2}{*}{$\begin{array}{l}\text { Possibilities for } \\
\text { competition }\end{array}$} & Austria & 4 & 3 & 9 & 3 & 1 \\
\hline & Czech Republic & 3 & 5 & 4 & 4 & 4 \\
\hline \multirow{2}{*}{$\begin{array}{l}\text { Getting an overview of } \\
\text { learning content before } \\
\text { learning lessons }\end{array}$} & Austria & 7 & 9 & 4 & 0 & 0 \\
\hline & Czech Republic & 3 & 7 & 4 & 3 & 3 \\
\hline \multirow{2}{*}{$\begin{array}{l}\text { Possibilities for self- } \\
\text { evaluation are } \\
\text { appreciated }\end{array}$} & Austria & 4 & 8 & 8 & 0 & 0 \\
\hline & Czech Republic & 2 & 8 & 7 & 3 & 0 \\
\hline
\end{tabular}

\section{Reflection and Conclusion}

This contribution set out to identify online learning preferences of Bachelor students taking a degree of logistics in Austria and the Czech Republic. The generated insights shall help to offer e-learning material that is broadly accepted at both sides of the geographical border. Given that this investigation is part of a bigger Interreg project that seeks to offer CLIL elements and online learning material in English, German and the Czech language, deeper knowledge of societal and disciplinary preferences is helpful to generate material that is appreciated by students, teachers and industry alike. In a next step, this material will be adapted in line with the findings to generate the best possible added value.

\section{Limitations}

Given the limited number of participants, this cross-border investigation cannot serve as a frame of reference for other studies. Furthermore, the focus of this contribution was placed on Bachelor students of logistics only, which was further narrowed down by a restricted regional perspective, namely the Czech Republic and Upper Austria. Further research may take more participants into account and also embrace more geographical regions. In addition, it may be interesting to also draw on other disciplines and relate the findings to the ones identified among the logistics students.

\section{Acknowledgements}

The project "CLIL" has been funded with support from the European Commission, the European Fund for Regional development (EFRE), and the Federal State of Upper Austria under the program INTERREG V-A Austria-Czech Republic 2014-2020”.

\section{References:}

- Amriani, Afifa. Aji, Aji F., Utomo, Andika. Y. and Junus, Kasiyah M. (2013), “An empirical study of gamification impact on e-Learning environment", in Computer Science and Network Technology (ICCSNT), 2013 3rd International Conference, IEEE, 265-269. Crossref

- Bolten, Jürgen (2003), Interkulturelle Kompetenz. (2. unv. Aufl.), Landeszentrale für politische Bildung: Thüringen.

- Brodbeck, Felix C., Frese, Michael, and Javidan, Mansour (2002), "Leadership made in Germany: Low on compassion, high on performance", in The Academy of Management Executive, 16(1), 16-29. Crossref

- Cmilt, Dazmin. D. (2015), Logistics Educational Needs for Logistics Undergraduate Program: A Case Study on the Malaysia Private Higher Education Institution.

- Dalton-Puffer, Christiane (2008), Outcomes and processes in Content and Language Integrated Learning (CLIL): current research from Europe. $\underline{\text { Crossref }}$

- Deterding, Sebastian, Sicart, Miguell, Nacke, Lennart, O'Hara, Kenton, and Dixon, Dan (2011), "Gamification: using game-design elements in non-gaming contexts", in CHI'11 extended abstracts on human factors in computing systems, ACM, 2425-2428. $\underline{\text { Crossref }}$

- Dixit, Shailja (2015), "Enhancing the Competitiveness of Textile Industry in an Emerging Economy: the Role of MSME", in SAMVAD, 9, 26-39.

- Felder, Richard. M., and Silverman, Linda. K. (1988), "Learning and teaching styles in engineering education", in Engineering education, 78(7), 674-681.

- Soloman, Barbara. A. (2000), "Learning styles and strategies" (accessed February 12, 2018), [available at 
http://www4.ncsu.edu/unity/lockers/users/f/felder/public/I LSdir/styles.htm].

- Fink Gerhard, Nový Ivan and Schroll-Machl Sylvia (2000), "Tschechische, österreichische und deutsche Kulturstandards in der Wirtschaftskooperation," in JEEMS, 5(4), 361-376. rossref

- Gaisch, Martina and Jadin, Tanja (2015), "Enhanced MOOCs for the conceptual age: a diversified lens on the MOOCversity", Position papers for European cooperation on MOOCs, Porto, Portugal, 2015, 120-129.

- Rammer, Victoria, Hrušková, Lenka, Krátká, Jana and Mádlová, Gabriela (2017), “Content Language Integrated Learning as a Driver for Enhanced Graduate Employability - A Cross-Cultural Study between Austria and the Czech Republic “ in Proceedings Cross-Cultural Business Conference 2017, Steyr, Österreich, 2017, 233-246.

- Hall, Edward T. (1976). Beyond Culture, Anchor, Garden City: NY

- Hofstede Geert (1984), “Culture's consequences: International differences in work-related values," Vol. 5. sage.

- Hofstede, Gert. J. (2012), Lokales Denken, globales Handeln: Interkulturelle Zusammenarbeit und globales Management (50807). CH Beck.

- House, Robert., Javidan, Mansour, Hanges, Paul and Dorfman, Peter (2002), "Understanding cultures and implicit leadership theories across the globe: an introduction to project GLOBE," in Journal of world business, 37(1), 3-10. Crossref

- Jadin, Tanja, and Gaisch, Martina (2016), "eMOOCs for Personalised Online Learning: A Diversity Perspective", in Proceedings of the European Stakeholders Summit (EMOOCS 2016), University of Graz: Austria, 69-80.

- Knap, Karel, and Novy, Ivan. (2017). "Czech Cultural Standards from the Perspective of the Top Management of German Companies", in Central European Business Review, 6(1), 76-91. Crossref

- Kolb, David A. (1984). Experience as the source of leraning and development. Englewood Cliffs: Pretience-Hall

- Kroeber Alfred L. and Kluckhohn Clyde (1952), "Culture: A critical review of concepts and definitions,"Papers. Peabody Museum of Archaeology \& Ethnology, Harvard University

- Marcus, Aaron and Gould, Emilie W. (2000), "Crosscurrents: cultural dimensions and global Web userinterface design", in interactions, 7(4), 32-46. $\underline{\text { Crossref }}$

- Muntean, Christina I. (2011), "Raising engagement in elearning through gamification", in Proc. 6th International Conference on Virtual Learning ICVL (Vol. 1). sn.
- Nový, Ivan, and Schroll-Machl, Sylvia (2015), Interkulturní komunikace: Češi a n ěmci. Prague: Management Press.

- Overgaard, Louise (2010), “An analysis of Indian Culture in an Era of Globalisation”, Department of Language and Business Communication, Aarhus School of Business, Aarhus University.

- Schroll-Machl Sylvia and Nový Ivan (2008), Perfekt geplantoder genial improvisiert? München: Reiner Hampp Verlag.

- Shea, Peter J., Pickett, Alexander M., and Pelz, William E. (2003). "A follow-up investigation of "teaching presence"" in the SUNY Learning Network, Journal of Asynchronous Learning Networks, 7(2), 61-80. Crossref

- Thomas Alexander, Schroll-Machl Sylvia, Kammhuber Stefan and Kinast Eva-Ulrike (2009), Handbuch Interkutlruelle Kommunikation und Kooperation: Band 1 und 2 zusammen, Vol. 1, Vanden-hoeck \& Ruprecht.

- Trompenaars, Fons (1993) Handbuch globales Managen: Wie man kulturelle Unterschiede im Geschäftsleben versteht. Econ-Verlag.

- Hampden-Turner, Charles (2011). Riding the waves of culture: Understanding diversity in Global Business. Nicholas Brealey Publishing.

- Urh, Marko, Vukovic, Goran, and Jereb, Eva (2015), “The model for introduction of gamification into e- learning in higher education", in Procedia-Social and Behavioral Sciences, 197, 388-397. Crossref

- Zaric, Nadja, Scepanović, Snezana, Vujicic, Tijana, Ljucovic, Jelena, \& Davcev, Danco (2017), “The Model for Gamification of E-learning in Higher Education Based on Learning Styles“, in International Conference on ICT Innovations, Springer, Cham, 2665-273. Crossref 